\title{
Effects of sea stars and crabs on sea scallop Placopecten magellanicus recruitment in the Mid-Atlantic Bight (USA)
}

\author{
Deborah R. Hart* \\ National Marine Fisheries Service, Northeast Fisheries Science Center, 166 Water Street, Woods Hole, \\ Massachusetts 02543, USA
}

\begin{abstract}
Relationships between recruitment of the Atlantic sea scallop Placopecten magellanicus and the abundances of 3 types of invertebrate predators, the sand star Astropecten americanus, the common sea stars Asterias spp. and the crabs Cancer spp., were investigated using data from large-scale scallop surveys in the Mid-Atlantic Bight (USA). Both asteroid groups appeared to reduce sea scallop recruitment, with significantly lower recruitment in areas where the sea stars were in high abundance. No significant effect of Cancer spp. crabs on scallop recruitment was detected. Very high densities of $A$. americanus, no sea scallop recruitment, and low Asterias spp. densities were observed in all stations with depths $>85 \mathrm{~m}$, and in many stations between 65 and $85 \mathrm{~m}$. Astropecten americanus may be a dominant component of the deep-water $(>75 \mathrm{~m}$ ) benthic community in the Mid-Atlantic Bight that is capable of excluding both sea scallops and Asterias spp. from areas where A. americanus are highly abundant.
\end{abstract}

KEY WORDS: Recruitment · Predation · Scallop · Sea star · Placopecten magellanicus $\cdot$ Asterias spp. Astropecten spp. · Cancer spp.

Resale or republication not permitted without written consent of the publisher

\section{INTRODUCTION}

Recruitment is an important determinant of the population dynamics of most benthic organisms with planktonic larvae. Yet, despite intensive study, there is still limited understanding of the factors that determine the spatio-temporal patterns of recruitment (Ólafsson et al. 1994, Gosselin \& Qian 1997, Hunt \& Scheibling 1997, Fraschetti et al. 2003). While the supply of larvae can influence the level of recruitment, much variation in recruitment cannot usually be explained by this factor. This implicates processes occurring soon after settlement as important determinants of recruitment. During the first 4 mo after settlement, mortality of benthic invertebrates is typically greater than $80 \%$ and often exceeds 98\% (Gosselin \& Qian 1997). Processes that may contribute to this mortality include predation, starvation, competition for food or space, disease, toxic algae, temperature extremes and physical disturbance. Of these, predation has been best documented, and often appears to be responsible for the bulk of postsettlement mortality. For example, juvenile surf clams Spisula solidissima occur at densities of $2500 \mathrm{~m}^{-2}$ or more early after settlement, but these clams can suffer mortality approaching $100 \%$ within 9 mo, mainly due to crab predation (MacKenzie et al. 1985). Even in cases where larval supply may limit recruitment, such as with the bay scallop Argopecten irradians, predation on juveniles can strongly affect the spatio-temporal patterns of recruitment (Peterson \& Summerson 1992, Bishop et al. 2005).

Like most other benthic invertebrates, juvenile Atlantic sea scallops Placopecten magellanicus suffer high mortality. McGarvey et al. (1992) estimated the probability of survival on Georges Bank of a sea scallop egg to Age 2 to be $1.26 \times 10^{-7}$, and the probability of survival from the larval stage to Age 2 to be $9.2 \times$ $10^{-6}$. While considerable mortality occurs during the pelagic larval stage, survivorship during the early post-settlement stage must also be low. Short-term 
survival of seeded juvenile scallops in enhancement experiments range from 1 to $40 \%$, with the majority of the mortality due to predation (Cliche et al. 1994, Barbeau et al. 1996). Merrill \& Edwards (1976) observed small $(<10 \mathrm{~mm})$ juvenile sea scallops at densities of over $2000 \mathrm{~m}^{-2}$ on a navigation buoy. By comparison, the mean densities of 2 yr old sea scallops in surveyed US scallop grounds is several orders of magnitude lower, about $0.05 \mathrm{~m}^{-2}$, corresponding to about 100 recruits tow $^{-1}$ (assuming $43 \%$ dredge efficiency, Gedamke et al. 2004). The present paper relates the spatial patterns of sea scallop recruitment to abiotic factors such as depth and to the abundances of 3 types of potential predators: the sand star Astropecten americanus, the common sea stars Asterias spp., and the crabs Cancer spp. In particular, I test the hypothesis that scallop recruitment is negatively related to the abundances of Cancer spp. and the 2 sea star groups.

The sea star Astropecten americanus is a common inhabitant of soft-bottom areas of the NW Atlantic, ranging along the continental shelf and slope from Cape Hatteras to the southern flank of Georges Bank (Boesch 1979, Franz et al. 1981). Astropecten spp. forage on the sediment surface, swallow their prey whole through their mouth, and then bury themselves in the sediment while digesting their prey. Their diet consists primarily of small invertebrates, and they are typically generalist feeders, although they often show preferences for certain prey items, usually small mollusks (Christensen 1970, Sloan 1980, Franz \& Worley 1982, Lemmens et al. 1995). The stomach contents of $A$. americanus indicate that this species consumes primarily small mollusks and crustaceans (mostly $<3 \mathrm{~mm}$, and all $<12 \mathrm{~mm}$ ), including juvenile sea scallops (Franz \& Worley 1982, Smereka 2003). The subtropical $A$. articulatus, whose distribution overlaps that of $A$. americanus near Cape Hatteras (Boesch 1979, Franz et al. 1981), is a predator of juvenile calico scallops Argopecten gibbus off North Carolina (Schwartz \& Porter 1977).

The sea stars Asterias spp. (A. forbesi and $A$. vulgaris $=A$. rubens, Franz et al. 1981) are widely distributed in the MidAtlantic Bight area (Boesch 1979, Franz et al. 1981), and consume a wide variety of prey, including scallops and many other bivalves (Sloan 1980). Asterias spp. can consume much larger prey items than Astropecten spp. by prying open their prey and everting their stomach. However, they also can consume smaller prey such as juvenile scallops (Smith 1940, Vevers 1949, Sloan 1980, Barbeau et al. 1996). The introduced sea star $A$. amurensis was shown to reduce the post-settlement survivorship of the bivalve Fulvia tenuicostata in Tasmania (Ross et al. 2002).

Cancer spp. (the rock crab C. irroratus and the Jonah crab C. borealis) are also common inhabitants of the NW Atlantic, and can prey on juvenile sea scallops (Elner \& Jamieson 1979). C. irroratus was the most important predator on juvenile scallops during seeding enhancement trials in Canada, although Asterias spp. predation was also a significant contributor to seeded scallop mortality (Cliche et al. 1994, Barbeau et al. 1996, 1998).

\section{MATERIALS AND METHODS}

Study area. Samples (Fig. 1) were taken in the MidAtlantic Bight area, a portion of the eastern North American continental shelf, between $36^{\circ} 30^{\prime}$ and $41^{\circ} \mathrm{N}$, and $71^{\circ} 30^{\prime}$ and $74^{\circ} 50^{\prime} \mathrm{W}$, in depths between 27 and $104 \mathrm{~m}$. This area has temperate water temperatures (Table 1) and sandy sediments often mixed with shells, with occasional patches of sandy gravel and sandy silt (Boesch 1979, Wigley \& Theroux 1981). Samples taken from a more northeasterly region (Georges Bank and vicinity), between $40^{\circ} 24^{\prime}$ and $42^{\circ} 10^{\prime} \mathrm{N}$, and $66^{\circ} 25^{\prime}$ and $69^{\circ} 50^{\prime} \mathrm{W}$, were used for comparative purposes.
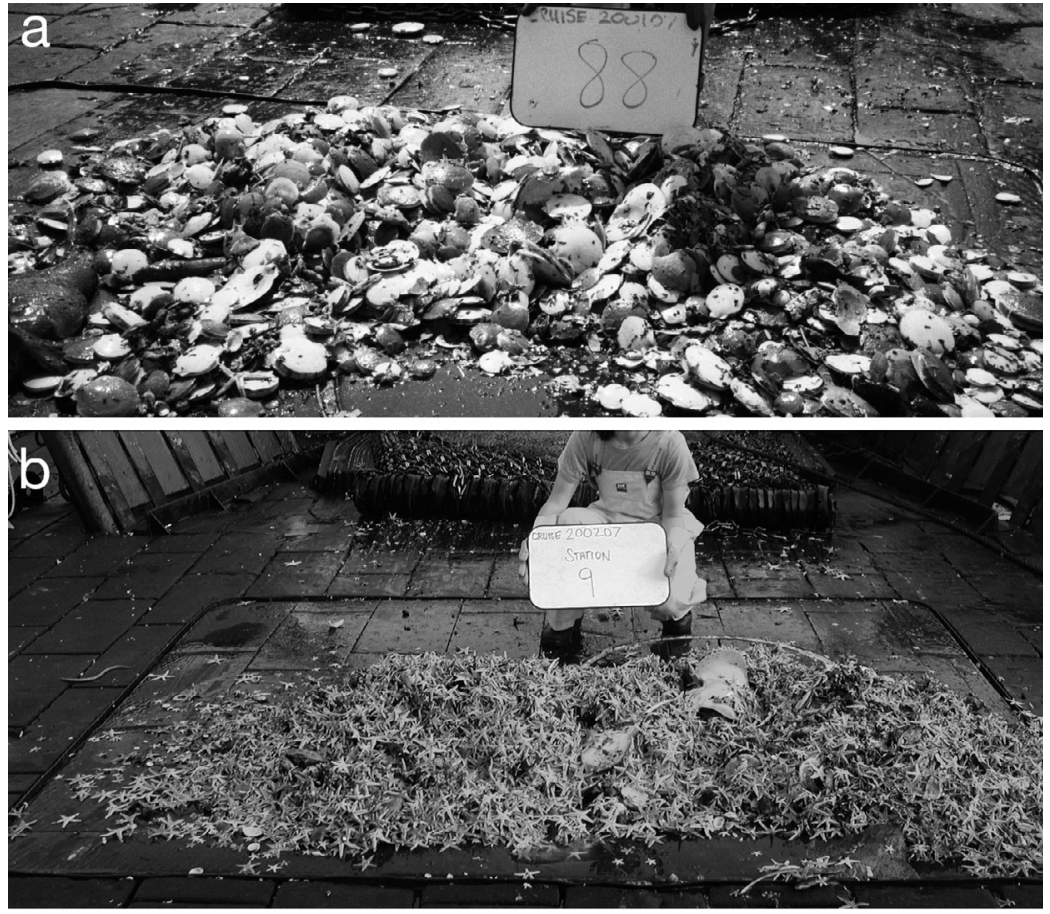

Fig. 1. Example catches from National Marine Fisheries Service (NMFS) sea scallop survey. In (a) catch was dominated by Placopecten magellanicus, many of them small 'recruit' scallops; in (b) catch was dominated by sea star Astropecten americanus 
Table 1. Bottom temperatures $\left({ }^{\circ} \mathrm{C}\right)$ from CTD casts during March and September 1998 to 2002 (near seasonal minimum and maximum temperatures) in the Mid-Atlantic Bight study area as a function of depth

\begin{tabular}{|lrccc|}
\hline \multirow{2}{*}{$\begin{array}{l}\text { Depth } \\
(\mathrm{m})\end{array}$} & \multicolumn{2}{c}{ March } & \multicolumn{2}{c|}{ September } \\
& Mean & Range & Mean & Range \\
$27-39$ & 6.3 & $3.7-10.3$ & 16.7 & $9.6-23.5$ \\
$40-54$ & 6.6 & $4.2-10.2$ & 11.6 & $8.2-20.6$ \\
$55-69$ & 7.8 & $4.2-13.6$ & 10.5 & $7.8-18.7$ \\
$70-84$ & 9.5 & $5.2-13.6$ & 10.4 & $7.7-16.8$ \\
$85-104$ & 10.5 & $4.8-13.9$ & 12.7 & $8.3-14.4$ \\
\hline
\end{tabular}

Sampling protocol. Samples were taken aboard the RV 'Albatross IV' during 2000 to 2002 on the annual summer National Marine Fisheries Service (NMFS) sea scallop survey (Fig. 1). The survey followed a random-stratified design, using a $244 \mathrm{~cm}$ wide modified New Bedford scallop dredge with $5.1 \mathrm{~cm}$ rings and a $3.8 \mathrm{~cm}$ mesh plastic liner (Serchuk \& Wigley 1986, NEFSC 2004). Tows were conducted for $15 \mathrm{~min}$ at a speed of $7.04 \mathrm{~km} \mathrm{~h}^{-1}$. Scallops, finfishes and Cancer spp. were removed from the catch and recorded. Sea scallops were measured in $5 \mathrm{~mm}$ size-bins; the raw size-frequency was then adjusted to take into account the selectivity of the liner (NEFSC 2004). After adjustment, the survey dredge had similar efficiency as a commercial dredge for larger scallops, and (unlike unlined commercial scallop dredges with $8.8 \mathrm{~cm}$ rings) was able to retain scallops with similar efficiency down to the $3.8 \mathrm{~cm}$ mesh-size of the liner (NEFSC 2004). Sea scallop 'recruits' were identified as those between 40 and $69 \mathrm{~mm}$ (a $40 \mathrm{~mm}$ scallop in the Mid-Atlantic would grow to $69 \mathrm{~mm}$ in $1 \mathrm{yr}$ according to the growth curve of Serchuk et al. 1979), roughly corresponding to the year class spawned 2 yr prior to the survey (Thouzeau et al. 1991). Cancer spp. were counted and weighed in aggregate, and in some selected stations in 2001 and 2002 , they were counted and weighed by species. Substrate and a number of invertebrate taxa were assessed qualitatively by noting whether they were absent, present or a dominant component of the catch. Most fine-grained substrate (e.g. sand) will not be retained by the liner, so its absence from the catch does not necessarily indicate its absence from the bottom sediment, especially in deep-water stations where the longer haul-back time causes more of the substrate to be washed out of the dredge.

At pre-determined stations ( $\mathrm{n}=335$ over the $3 \mathrm{yr}$, about half of all stations in the Mid-Atlantic Bight), the catch was subsampled for sea stars. After removal of scallops, crabs and finfishes, the remainder of the catch was quantified by shoveling into 461 baskets. Random subsamples of the baskets were collected to fill a 51 bucket. Sea stars were sorted into Astropecten spp. and Asterias spp. and counted from the subsample, and each was weighed in aggregate. The total number and weight of the 2 asteroid types could then be calculated by expanding the subsample by the total quantity in the baskets. No attempt was made to further separate the sea stars by species on deck, although all Astropecten spp. samples that were examined closely on deck or frozen and later examined were A. americanus, while both Asterias forbesi and $A$. vulgaris were common, with $A$. vulgaris tending to occur in deeper and more northerly waters than $A$. forbesi. Other genera of sea stars, such as Henricia, Luidia and Leptasterias were occasionally observed at low densities in the subsamples, but were not included in this study. All data reported here are only from those stations in the Mid-Atlantic Bight where sea star subsampling occurred. Similar data was also collected on Georges Bank and neighboring areas, and will be used herein for comparative purposes.

Data analysis. As initial exploratory techniques, Pearson correlation coefficients between variables were computed, and relationships between abundances $\ln (x+1)$-transformed and depth or latitude were plotted and fitted using linear or quadratic regression as well as lowess smoothers with stiffness of 0.75 (Chambers et al. 1983). More detailed analyses were performed using backward stepwise linear regression (variables were removed if they were not statistically significant at $p=0.05)$. Response variables (e.g. scallop recruitment) were $\ln (x+1)$-transformed to obtain approximately normal residual patterns. Initial ANCOVA analysis indicated that the results did not significantly depend on the sampling year, sediment type observed (e.g. sand, gravel, mud), or on the absence, presence, or dominance of sand dollars in the catch. These factors were therefore not further considered in the analysis. We used 2 sample $t$-tests, $\ln (x+1)$ transformed in order to meet the requirements of approximate normality and homogeneity of variances, to compare scallop recruitment at high and low predator densities. All statistical analyses were performed using the software package Statistica 6.1 (StatSoft).

\section{RESULTS}

Scallop recruitment was strongest south of Hudson Canyon and in intermediate depths (Figs. 2 \& 3a,b). Astropecten americanus were always highly abundant in the deeper stations (>75 m, Figs. 2a \& 3c,d). They tended to be more common in the southern areas, and were often absent from shallow northerly stations. Note the spatial partitioning of high A. americanus and sea scallop catches. Asterias spp. were more common in shallower depths and at higher latitudes (Figs. 2b \& 

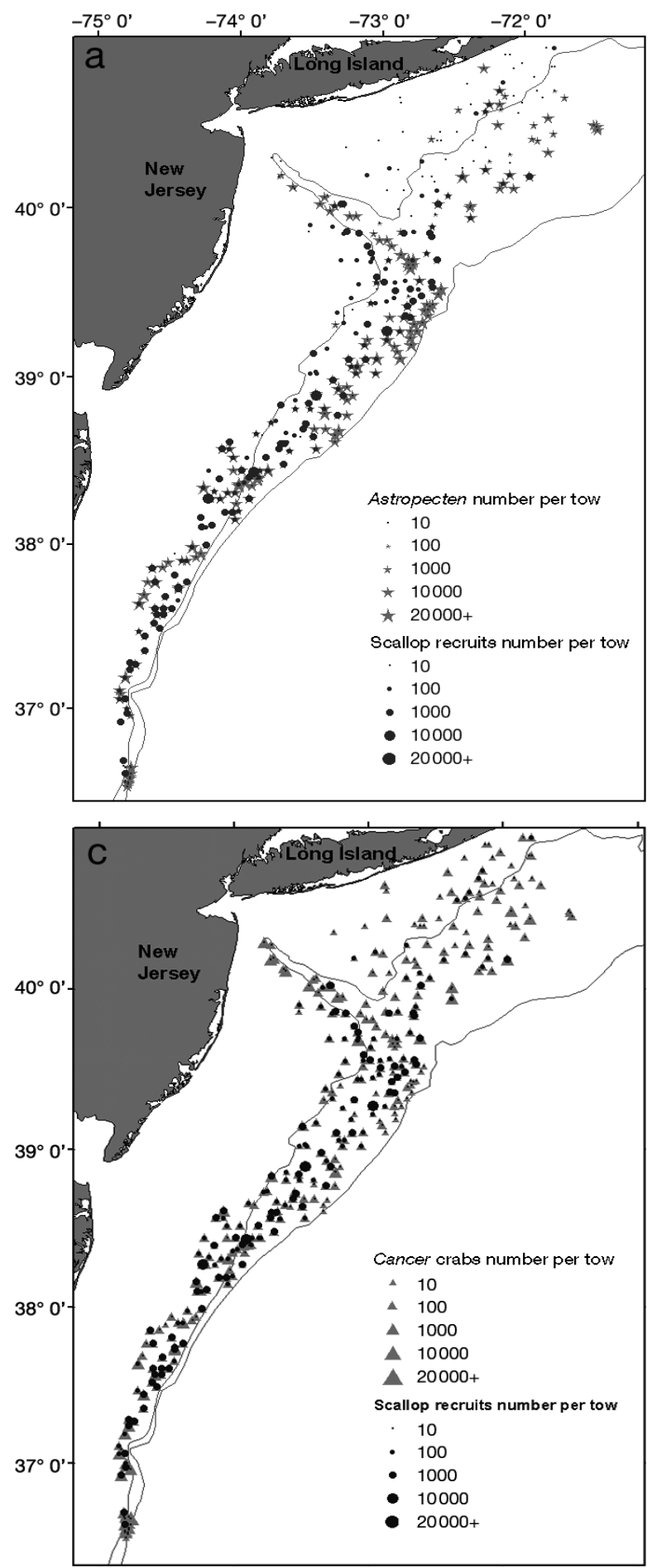

3e,f), Cancer spp. were slightly more common in the southern latitudes and at moderate depths (Figs. 2c \& $3 g, h)$. Of the crabs that were identified to species (about $47 \%$ of the total), $78 \%$ were C. irroratus, with the remainder $C$. borealis.

Bivalve shells (most commonly those of Placopecten magellanicus and the clams Arctica islandica, Spisula

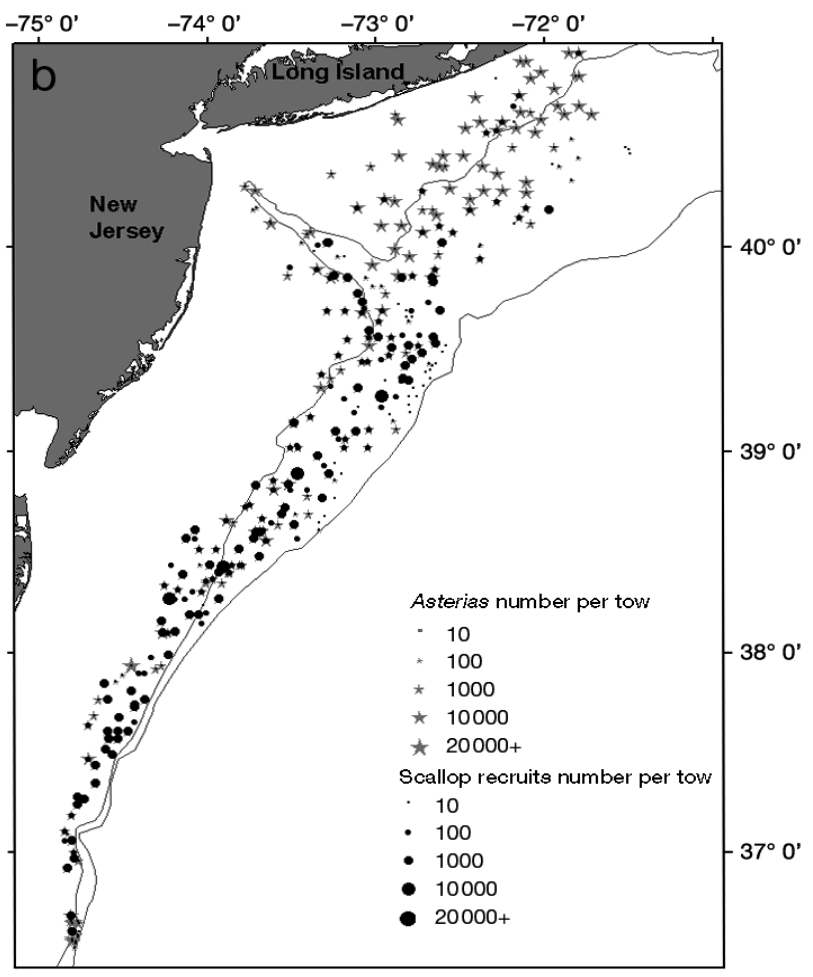

Fig. 2. Survey catches of scallop Placopecten magellanicus recruits (circles) in Mid-Atlantic Bight together with (a) Astropecten americanus (stars), (b) Asterias spp. (stars) and (c) Cancer spp. (triangles); 50 and $100 \mathrm{~m}$ isobaths are also shown. Surveyed area runs from off Chesapeake Bay north to Long Island, New York. Hudson Canyon can be seen off of New Jersey where $50 \mathrm{~m}$ isobath bends towards land

solidissima, Ensis spp., and Astarte spp.) and sand were the most commonly observed components of the substrate (Table 2). The sand dollar Echinarachnius parma often dominated the catches in the shallower stations (Table 3). Other common invertebrates observed included sea urchins, sponges, gastropods (e.g. the whelks Buccinum spp., and the moon shell Lunatia 

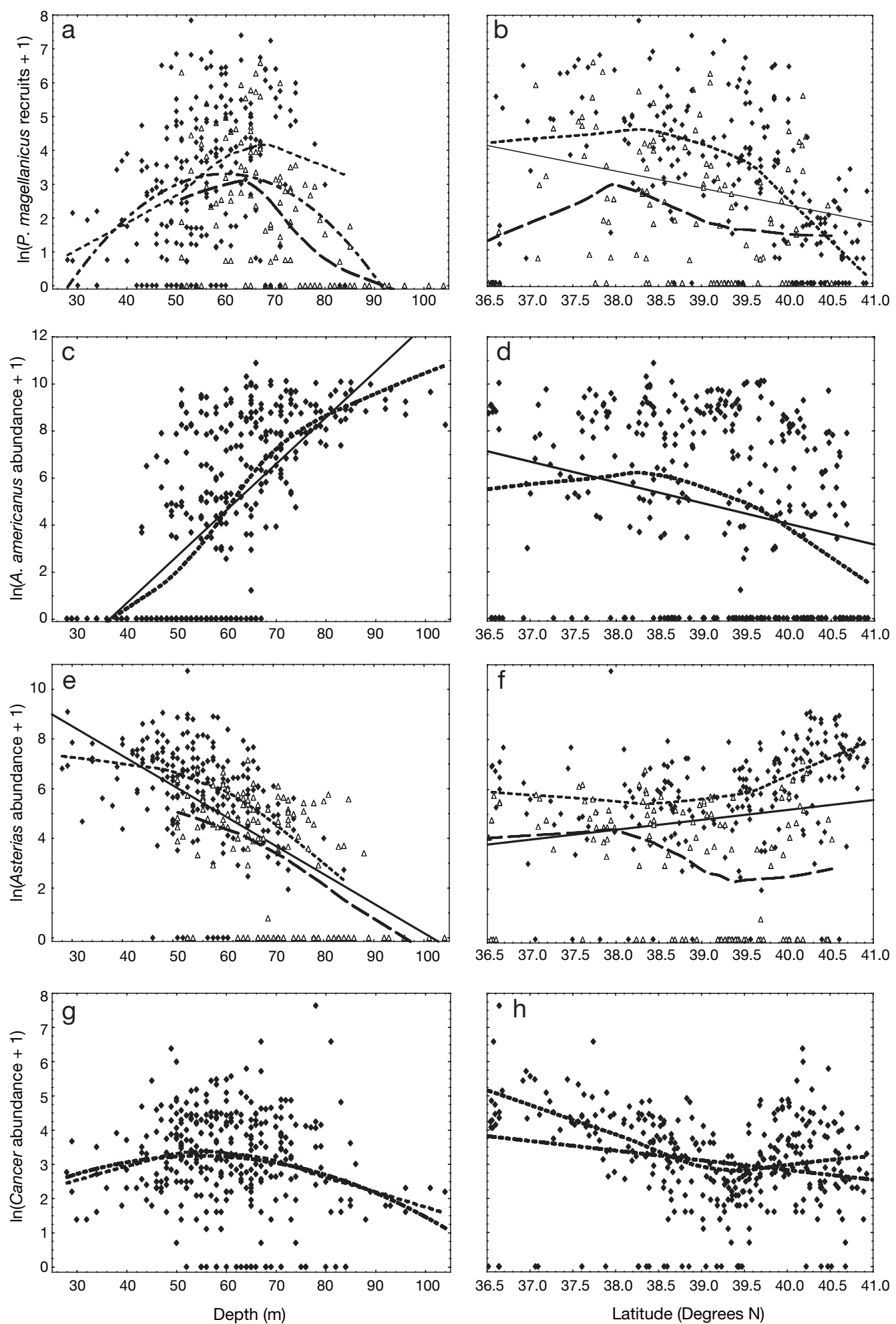

Fig. 3. Distribution of survey catches (nos. tow ${ }^{-1}$ ) in the Mid-Atlantic Bight of (a,b) Placopecten magellanicus recruits, (c,d) Astropecten americanus, $(\mathrm{e}, \mathrm{f})$ Asterias spp., and $(\mathrm{g}, \mathrm{h})$ Cancer spp. as a function of depth $(\mathrm{a}, \mathrm{c}, \mathrm{e}, \mathrm{g})$ and latitude $(\mathrm{b}, \mathrm{d}, \mathrm{f}, \mathrm{h})$. All response variables were $\ln (x+1)$-transformed. Simple linear regression fits to all data points (continous lines) or, in graphs for $P$. magellanicus (a) and Cancer spp. (g) vs. depth, quadratic regression fits (dashed line), as well as lowess-smoothed lines (stiffness $=0.75$; dashed line) are also shown. Data points in P. magellanicus $(\mathrm{a}, \mathrm{b})$ and Asterias spp. $(\mathrm{e}, \mathrm{f})$ graphs are separated into stations where A. americanus biomass was high $\left(>10 \mathrm{~kg} \mathrm{tow}^{-1}, \Delta\right)$, and low $\left(<10 \mathrm{~kg} \mathrm{tow}^{-1}, \diamond\right)$. In these cases, lowess smoothers are given for both high (long-dashed line) and low (short-dashed line) A. americanus stations, with the regression fit to all data 
Table 2. Percentage of stations in 2000 to 2002 NMFS (National Marine Fisheries Service) scallop surveys containing various substrates as a function of depth. ${ }^{*}$ : category that was frequently dominant component of substrate

\begin{tabular}{|lrcccc|}
\hline $\begin{array}{l}\text { Depth } \\
(\mathrm{m})\end{array}$ & $\begin{array}{c}\text { Bivalve } \\
\text { shells }\end{array}$ & $\begin{array}{c}\text { Gastropod } \\
\text { shells }\end{array}$ & Sand & $\begin{array}{c}\text { Gravel/ } \\
\text { cobble }\end{array}$ & $\begin{array}{c}\text { Mud/ } \\
\text { clay }\end{array}$ \\
\hline $27-39$ & $100^{*}$ & 90 & $87^{*}$ & 0 & 0 \\
$40-54$ & $97^{*}$ & 81 & $61^{*}$ & 10 & 4 \\
$55-69$ & $100^{*}$ & 77 & $60^{*}$ & 9 & 7 \\
$70-84$ & $100^{*}$ & 61 & $45^{*}$ & 4 & 11 \\
$85-104$ & $100^{*}$ & 74 & 43 & 9 & 4 \\
\hline
\end{tabular}

heros) and worms (e.g. the polychaete Aphrodite sp.). Skates, primarily the little skate Leucoraja erinacea, were the most common demersal finfishes observed (Table 4). Flounder (mostly the gulfstream flounder Citharichthys arctifrons and the fourspot flounder Paralichthys oblongus), hakes (primarily the spotted hake Urophycis regia and the red hake U. chuss), and goosefish Lophius americanus were other common demersal finfishes in the study area.

As a preliminary exploration of the relationships among scallops, sea stars and crabs, a correlation matrix was computed (Table 5), relating abundance and mean weight of Astropecten americanus, Asterias spp. and Cancer spp., with latitude, depth, and sea scallop recruits. There were significant negative correlations between $A$. americanus abundance, A. americanus mean weight, Asterias spp. number and sea scallop recruitment. Abundances of both sea star groups as well as sea scallop recruits were significantly correlated with depth, and abundances of all biotic groups were significantly correlated with latitude.

To further examine the effects of predation and other factors on sea scallop recruitment, a multiple regression was performed using Astropecten americanus, Asterias spp. and Cancer spp. abundance and mean weight, together with latitude, depth and depthsquared (in order to account for the apparent nonlinear relationship of sea scallop recruitment with depth; Fig. 3a) as predictors of Placopecten magellani-

Table 3. Percentage of stations in 2000 to 2002 NMFS scallop surveys containing live invertebrates as a function of depth. * : category that was frequently dominant component of catch

\begin{tabular}{|lcccccccc|}
\hline $\begin{array}{l}\text { Depth } \\
(\mathrm{m})\end{array}$ & $\begin{array}{c}\text { Sand } \\
\text { dollars }\end{array}$ & $\begin{array}{c}\text { Sea } \\
\text { urchins }\end{array}$ & Sponges & $\begin{array}{c}\text { Gastro- } \\
\text { pods }\end{array}$ & $\begin{array}{c}\text { Ascid- } \\
\text { ians }\end{array}$ & $\begin{array}{c}\text { Anem- } \\
\text { ones }\end{array}$ & $\begin{array}{c}\text { Barn- } \\
\text { acles }\end{array}$ & \\
\hline $27-39$ & $65^{*}$ & 45 & 74 & 81 & 32 & 3 & 0 & 42 \\
$40-54$ & $58^{*}$ & 67 & 70 & 73 & 35 & 2 & 6 & 46 \\
$55-69$ & $43^{*}$ & 51 & 63 & 74 & 39 & 4 & 5 & 45 \\
$70-84$ & 14 & 15 & 48 & 58 & 20 & 4 & 4 & 33 \\
$85-104$ & 9 & 9 & 52 & 48 & 39 & 17 & 0 & 30 \\
\hline
\end{tabular}

Table 4. Major finfishes in catch (mean no. tow ${ }^{-1}$ ) during 2000 to 2002 NMFS scallop surveys as a function of depth

\begin{tabular}{|lcrrc|}
\hline Depth $(\mathrm{m})$ & Skates & Flounder & Hakes & Goosefish \\
\hline $27-39$ & 44.7 & 10.0 & 1.9 & 0.8 \\
$40-54$ & 15.6 & 7.9 & 11.6 & 2.2 \\
$55-69$ & 12.9 & 11.8 & 22.6 & 2.5 \\
$70-84$ & 2.9 & 12.7 & 8.2 & 2.2 \\
$85-104$ & 1.1 & 12.7 & 3.3 & 1.2 \\
\hline
\end{tabular}

cus recruitment, ln $(x+1)$-transformed. Of the independent variables examined, 6 were significant predictors of sea scallop recruitment: A. americanus and Asterias spp. abundance, A. americanus mean weight, latitude, depth and depth-squared, with all but depth negatively associated with scallop recruitment. After the non-significant variables were eliminated via a backward stepwise procedure, the latitude variable was no longer significant, and the final regression, with the remaining 5 significant predictors (Table 6a; see also Fig. 4), had a combined $\mathrm{R}^{2}$ of 0.37 .

Because depth is correlated with abundance of both Astropecten americanus and Asterias spp., there is some confounding of these variables in the multiple regression. This creates some uncertainty as to whether the reductions in sea scallop recruitment at depth extremes is mainly due to sea star predation or to some other effect related to depth (e.g. temperature). To help separate the effects of depth from those of sea stars, sea scallop recruitment was binned by depth categories ( 27 to 39,40 to 54,55 to 69,70 to 84 and 85 to $104 \mathrm{~m}_{;} \mathrm{n}=12,95,151,64$ and 13 , respectively), and by low or high sea star abundance or biomass (Fig. 5; see also Fig. 3a). A. americanus was separated by biomass ( $=$ abundance $\times$ mean size $)$ categories rather than by abundance, because both $A$. americanus abundance and mean size appear to affect scallop recruitment.

Mean sea scallop recruitment increased with increasing depth down to $70 \mathrm{~m}$, and declined thereafter at both high and low Astropecten americanus and Asterias spp. densities. At each depth range, sea scallop recruitment was greater in the low sea star categories (except in cases where there were no observations). Sea scallop recruitment was significantly greater at the low A. americanus stations in the 55 to $69 \mathrm{~m}$ (Student's $t=2.1, \mathrm{p}=$ $0.04)$ and 70 to $84 \mathrm{~m}(t=4.1, \mathrm{p}<0.001)$ depth ranges, and at the low Asterias spp. stations at 40 to $54(t=3.9, \mathrm{p}<$ $0.001)$ and 55 to $69 \mathrm{~m}(t=3.0, \mathrm{p}=$ 0.003) depths. 
Table 5. Astropecten americanus, Asterias spp. and Cancer spp. Pearson correlation coefficients between predator abundances and their mean weights (wt), Placopecten magellanicus recruitment, $\ln (x+1)$-transformed, latitude and depth in the Mid-Atlantic Bight. ${ }^{*} \mathrm{p}<0.05,{ }^{* *} \mathrm{p}<0.01,{ }^{* * *} \mathrm{p}<0.001$

\begin{tabular}{|c|c|c|c|c|c|c|c|c|c|}
\hline & 1 & 2 & 3 & 4 & 5 & 6 & 7 & 8 & 9 \\
\hline 1. A. americanus abundance & 1.00 & $-0.34^{* * *}$ & $-0.14^{*}$ & $0.15^{*}$ & $0.12^{*}$ & 0.03 & $-0.19^{*}$ & $0.45^{* *}$ & $-0.24^{*}$ \\
\hline 2. A. americanus mean wt & & 1.00 & 0.08 & 0.03 & 0.04 & 0.13 & $0.21^{* *}$ & $-0.18^{* *}$ & $-0.15^{*}$ \\
\hline 3. Asterias spp. abundance & & & 1.00 & -0.10 & -0.03 & 0.07 & $0.12^{* * *}$ & $-0.22^{* * *}$ & $-0.13^{* *}$ \\
\hline 4. Asterias spp. mean wt & & & & 1.00 & 0.03 & -0.08 & -0.10 & 0.06 & 0.00 \\
\hline 5. Cancer spp. abundance & & & & & 1.00 & $-0.17^{* *}$ & $-0.25^{* *}$ & 0.05 & -0.03 \\
\hline 6. Cancer spp. mean wt & & & & & & 1.00 & $0.41^{* * *}$ & 0.11 & $-0.19^{* *}$ \\
\hline 7. Latitude & & & & & & & 1.00 & $-0.25^{*}$ & $-0.27^{* *}$ \\
\hline 8. Depth & & & & & & & & 1.00 & $-0.12^{*}$ \\
\hline 9. P. magellanicus recruits & & & & & & & & & 1.00 \\
\hline
\end{tabular}

It is illuminating to compare the depth distributions of Placopecten magellanicus recruits and Asterias spp. from the Mid-Atlantic Bight with those of individuals collected to the north, on Georges Bank, Nantucket Shoals and the Great South Channel, since Astropecten americanus is rare in the latter areas (Franz et al. 1981). A. americanus was observed in only 26 of the 257 stations in Georges Bank and vicinity where sea star samples were taken, mostly in the deep-water stations on the southern edge of Georges Bank and Nantucket Shoals. At only 6 of these stations was A. americanus biomass greater than $10 \mathrm{~kg}_{\text {tow }}{ }^{-1}$. Of these 6 stations, sea scallop recruits and Asterias spp. were each absent from 4, and scallop recruits were present in low numbers in the other 2, similar to the pattern observed in the Mid-Atlantic Bight. Sea scallop recruitment in Georges Bank and neighboring areas was greatest between 60 and $90 \mathrm{~m}$, and declined more gently at depth extremes than in the

Table 6. Results of multiple regression of (a) significant predictors of sea scallop Placopecten magellanicus, recruitment $\ln (x+1)$-transformed, and (b) significant predictors of Asterias spp. abundance ln $(x+1)$-transformed. Coeff: raw predictor values; Std. coeff: results after independent variables were standardized to achieveunit standard deviations and zero means

\begin{tabular}{|lccccc|}
\hline Predictor & Coeff & SD & p-value & Std. coeff & SD \\
\hline (a) & & & & & \\
Intercept & -3.7 & 3.3 & 0.26 & & \\
$\begin{array}{l}\text { Astropecten americanus } \\
\text { abundance }\end{array}$ & -0.00011 & 0.00002 & $<10^{-6}$ & -0.35 & 0.06 \\
$\begin{array}{l}\text { Astropecten americanus } \\
\text { mean wt }\end{array}$ & -0.25 & 0.04 & $<10^{-6}$ & -0.32 & 0.06 \\
$\begin{array}{l}\text { Asterias spp. abundance } \\
\text { Depth }\end{array}$ & -0.00047 & 0.00013 & 0.0004 & -0.21 & 0.06 \\
$\begin{array}{l}\text { Depth-squared } \\
\text { (b) }\end{array}$ & 0.33 & 0.095 & 0.0007 & 1.64 & 0.48 \\
$\begin{array}{l}\text { Intercept } \\
\text { Astropecten americanus } \\
\quad \text { abundance }\end{array}$ & -0.0029 & 0.00068 & 0.00003 & -2.02 & 0.47 \\
Depth & 11.5 & 0.6 & $<10^{-6}$ & & \\
& -0.11 & 0.01 & $<10^{-6}$ & -0.52 & 0.05 \\
\hline
\end{tabular}

Mid-Atlantic (Fig. 6a). Asterias spp. abundance declined slightly at most with increasing depth (Fig. 6b), and were common in most deep-water stations, in contrast to the situation in the Mid-Atlantic.

The negative correlation between Astropecten americanus and Asterias spp. abundance suggests that there may be an antagonistic interaction between these 2 types of asteroids. To explore this further, Asterias spp. abundance, $\ln (x+1)$-transformed was regressed against depth and Astropecten americanus abundance. Both these variables were significant (Table 6b, Fig. 7), with a total $\mathrm{R}^{2}$ of 0.36. A. americanus mean weight was not a significant third predictor when added to the other 2 variables in the regression.

Astropecten americanus mean weight did not appear to be related to abundance in the cases where its abundance was less than about 5000 tow $^{-1}$ (Fig. 8). However, there was a substantial decline in mean weight as its abundance increased beyond this point. When stations at which there were $<5000 A$. americanus were removed, linear regression indicated that A. americanus abundance was a significant predictor of its mean weight $\left(t=-4.6, \mathrm{p}<0.001, \mathrm{R}^{2}=0.21\right)$. Depth was not a significant second predictor of mean weight when it was added to the regression $(t=-1.0, \mathrm{p}=0.31)$. Regressions also indicated that Asterias spp. mean weight (log-transformed) was significantly related to Asterias spp. $(t=-2.2, \mathrm{p}=0.03)$ and $A$. americanus $(t=3.0, \mathrm{p}=0.003)$ abundance, although the explanatory power of these variables was low $\left(\mathrm{R}^{2}=0.06\right)$. Cancer spp. mean weight (log-transformed) was significantly related to its abundance $(t=-3.5, \mathrm{p}<0.001)$, depth $(t=$ $-2.2, \mathrm{p}=0.03)$ and depth-squared $(t=$ $2.5, \mathrm{p}=0.01)$ 

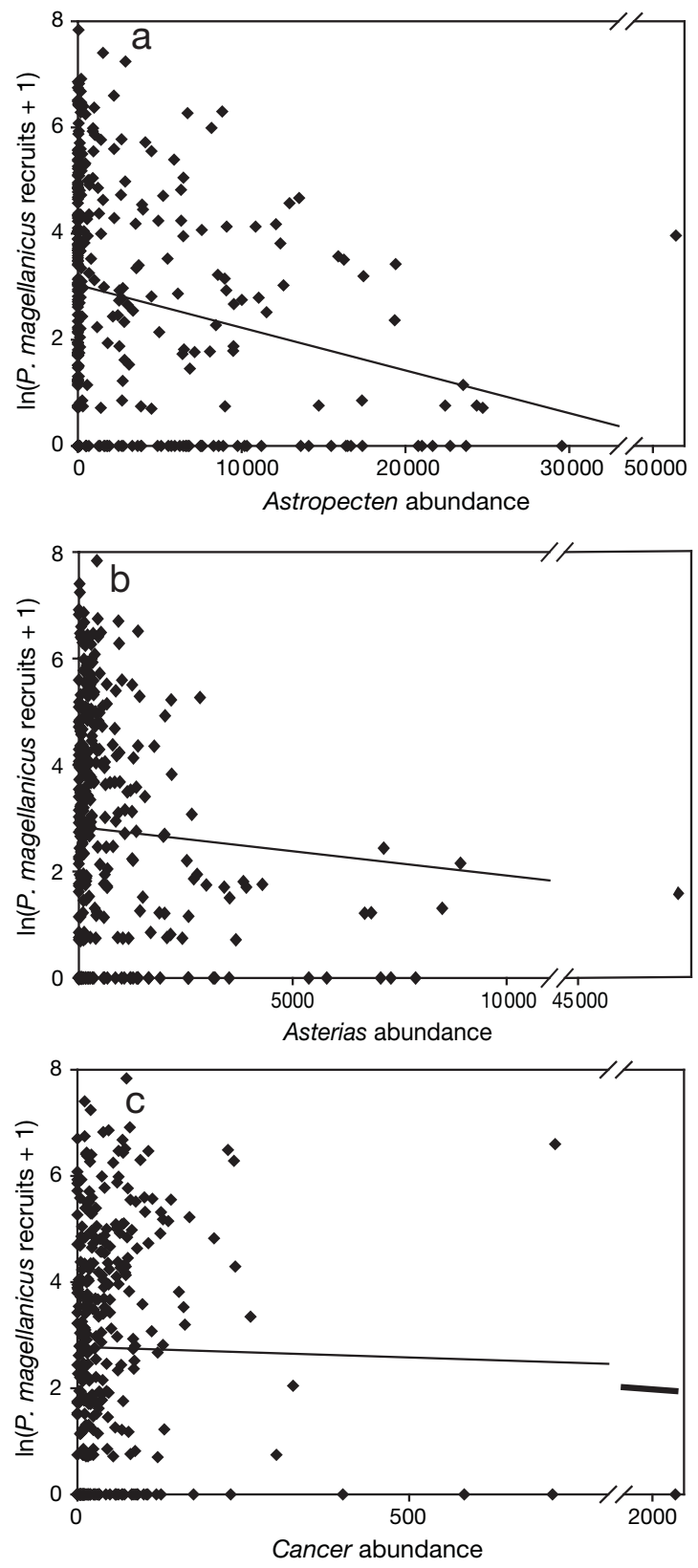

Fig. 4. Placopecten magellanicus recruitment vs. (a) Astropecten americanus, (b) Asterias spp., and (c) Cancer spp. abundance (nos. tow ${ }^{-1}$ ) in the Mid-Atlantic Bight. Simple linear regression lines are also shown. Data are $\ln (x+1)$ transformed

\section{DISCUSSION}

Sea scallop recruitment in the Mid-Atlantic Bight is significantly related to depth and to the abundances of Astropecten americanus and Asterias spp. The reduction in scallop recruitment at shallower depths is probably related to maximum bottom temperatures, which can approach or exceed the upper temperature at

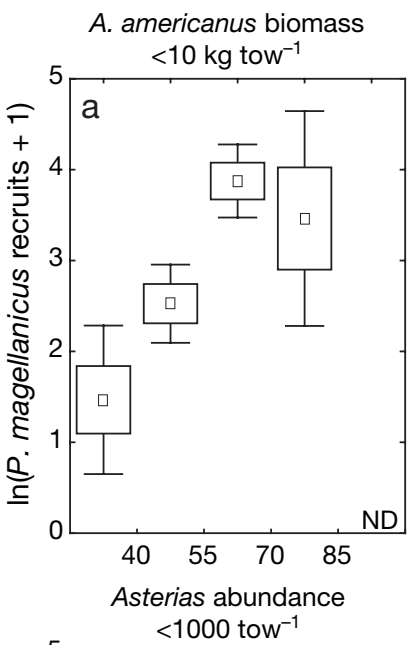

A. americanus biomass $>10 \mathrm{~kg} \mathrm{tow}^{-1}$

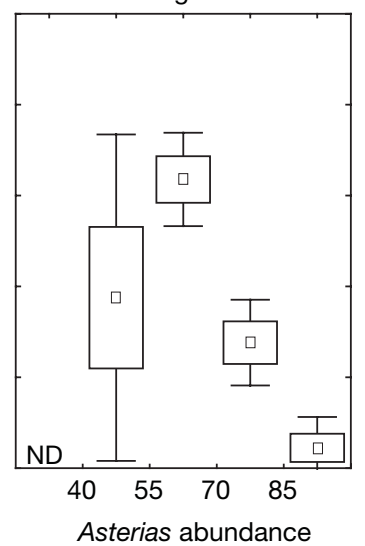

$>1000$ tow $^{-1}$

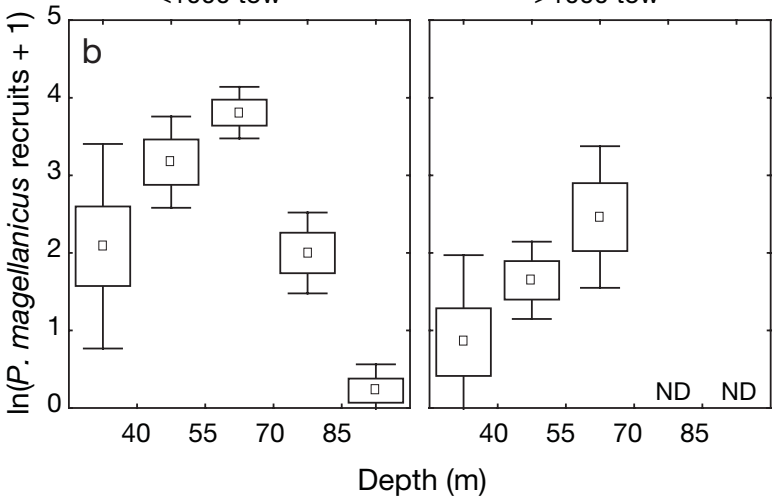

Fig. 5. Placopecten magellanicus. Box- and whisker plots showing mean (small inner square), SE of mean (outer box) and $95 \%$ confidence interval (whiskers) for scallop recruitment in the Mid-Atlantic Bight in 5 depth categories (27 to 39, 40 to 54,55 to 69,70 to 84 and 85 to $104 \mathrm{~m}$ ) at stations with (a) low and high Astropecten americanus biomass, and (b) low and high Asterias spp. abundance. ND: no observations. Data are nos. tow ${ }^{-1}, \ln (x+1)$-transformed

which sea scallops can survive (about $21^{\circ} \mathrm{C}$, Hart \& Chute 2004); the relatively high abundance of Asterias spp. in shallow waters probably also contributed to this pattern.

Sea scallop growth is typically slower in deep water, probably due to food limitation from reduced phytoplankton density (Schick et al. 1988, Thouzeau et al. 1991). Sea scallop recruitment would therefore be expected to decrease with increasing depth, since the spat will experience the high mortality suffered by small scallops for a longer period. However, the decline with increasing depth would be expected to be gradual were food limitation the main cause of this relationship, as was observed on Georges Bank. In the Mid-Atlantic Bight, sea scallop recruitment rapidly declined from a peak at about $60 \mathrm{~m}$ depth, to very low recruitment beyond $75 \mathrm{~m}$, and no observed recruitment deeper than $85 \mathrm{~m}$. Strong sea scallop recruitment 

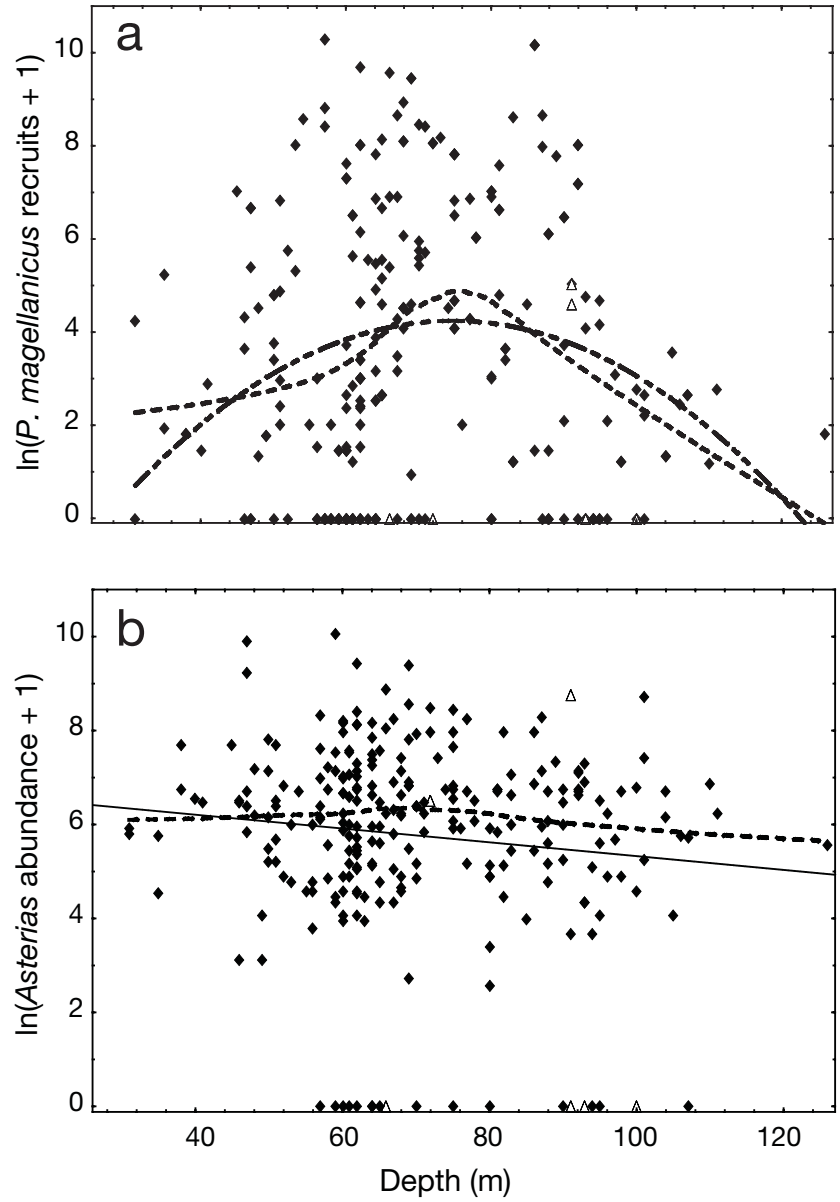

Fig. 6. Distribution of (a) Placopecten magellanicus recruitment, and (b) Asterias spp. abundance as a function of depth in areas surveyed NE of the Mid-Atlantic Bight (Georges Bank, Nantucket Shoals and Great South Channel); (nos. tow $^{-1}$ ) data are $\ln (x+1)$-transformed). $(\Delta)$ Six stations where Astropecten americanus biomass was $>10 \mathrm{~kg}^{-1}$ tow $^{-1}$. Simple linear regression (continous line). In (a) quadratic regression (dot-dashed line) was used, in (b) lowess-smoothed (dashed lines; stiffness $=0.75$ ) curves are also shown

was observed at $>90 \mathrm{~m}$ depth on Georges Bank, and sea scallops have been observed in even deeper water in the Gulf of Maine (Schick et al. 1988), so the absence of sea scallop recruits from deep-water in the MidAtlantic Bight is due to a factor not operating in these more northerly areas. Since Astropecten americanus is rare or absent on Georges Bank and in the Gulf of Maine, but common in deep water in the Mid-Atlantic Bight, it is probably the cause of the differential distribution of scallop recruits between these regions. Indeed, A. americanus was always observed at high abundance beyond $75 \mathrm{~m}$, and at even higher densities beyond $85 \mathrm{~m}$, corresponding well to the points where sea scallop recruitment strongly declined, and was then absent.

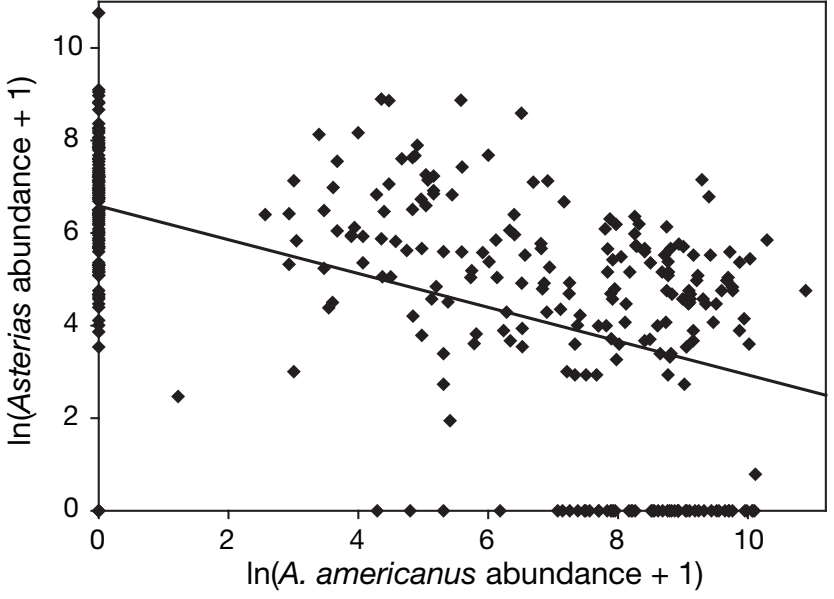

Fig. 7. Asterias spp. abundance vs. Astropecten americanus abundance (both in nos. tow ${ }^{-1}$ ), in the Mid-Atlantic Bight; data are $\ln (x+1)$-transformed; simple linear regression line is shown
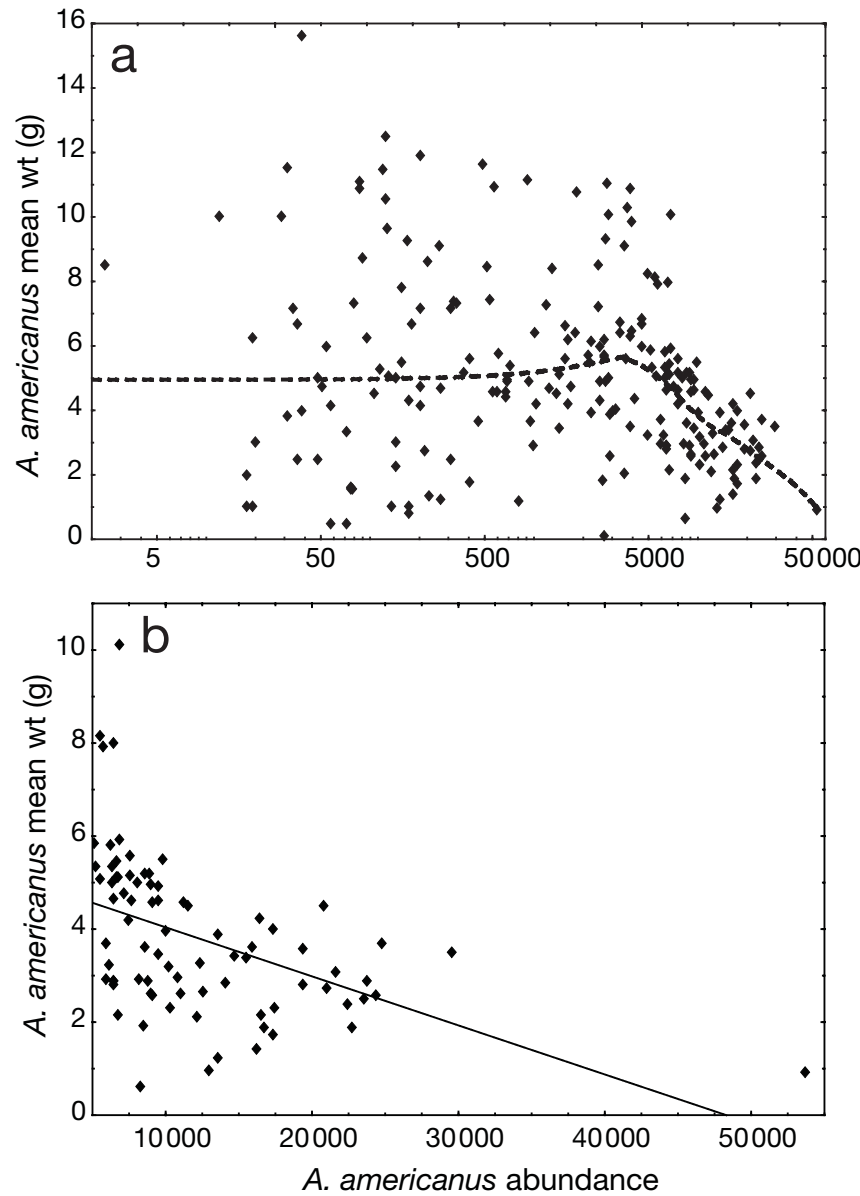

Fig. 8. Astropecten americanus. Mean weight (g) vs. abundance (nos. tow ${ }^{-1}$ ) in the Mid-Atlantic Bight for (a) all stations where $A$. americanus were caught (note log scale on $x$-axis) together with lowess line (stiffness $=0.75$ ), and $(b)$ stations where $>5000 \mathrm{~A}$. americanus were caught (linear regression line shown) 
In contrast to what has been observed during sea scallop enhancement experiments, no significant relationship was observed between Cancer spp. and sea scallop recruitment, although there was a hint of a negative correlation. It is possible that the densities of Cancer spp. in the Mid-Atlantic region were too low for them to make a substantial impact on scallop populations. Also, the mobility of Cancer spp. may mean that high density areas do not persist on an annual time scale, making it difficult to detect interactions involving Cancer spp. using the methodology of this study.

Finfishes do not appear to have a substantial influence on scallop recruitment in the Mid-Atlantic Bight. The most common benthic fish observed, the little skate Leucoraja erinacea, consumes mostly crustaceans and polychaetes (Collette \& Klein-MacPhee 2002). Of over 50000 prey items found in the stomachs of little skates recorded in the NEFSC (Northeast Fisheries Science Center) food-habits database (Link \& Almeida 2000), no scallops were identified, although about $2 \%$ of the items were unidentified bivalves. Also, the other benthic fishes (e.g. flounder and hakes) observed in this area rarely, if ever, consume scallops (scallops comprised $<0.1 \%$ of the prey items in the stomachs of spotted and red hake, and no scallops were observed in the stomachs of fourspot and gulfstream flounder, from the NEFSC food-habits database), and their depth distributions are not negatively correlated with that of sea scallops.

Studies in Canadian waters have indicated that sea scallop densities and recruitment are considerably higher in gravel or gravel-sand bottoms than in sand bottoms (e.g. Thouzeau et al. 1991). The level of sea scallop recruitment observed in this study in the MidAtlantic Bight, with almost entirely sand bottoms, is comparable or greater to that observed in harder bottom further north. It is possible that the nearly universal presence of shell substrate in the Mid-Atlantic Bight can substitute for gravel, providing sufficient attachment sites for settlement and possibly also some protection from predators, as has been noted for the Iceland scallop Chlamys islandica (Guay \& Himmelman 2004). Additionally, sea scallops may preferentially settle in gravel bottoms when available, as in Canada, but have no alternative but to settle in sand bottoms in the Mid-Atlantic Bight.

Sea scallop spawning-stock biomass and egg production in the Mid-Atlantic Bight were well above historical means during the 2000 to 2002 study period, and (possibly not coincidently) recruitment was also well above average (NEFSC 2004). However, recruitment remained low at depth extremes during this period. Moreover, the relationships observed here were consistent over the $3 \mathrm{yr}$ period, whereas larval settlement patterns tend to be highly variable (Fraschetti et al. 2003). These considerations suggest that larval supply is not responsible for the observed distribution of sea scallop recruitment with depth.

Franz \& Worley (1982) found 20 sea scallops (modal size $0.7 \mathrm{~mm}$ ) in the stomachs of 106 Astropecten americanus collected in November on Nantucket Shoals. Smereka (2003) found 38 scallops (shell heights 5 to $12 \mathrm{~mm}$ ) in the stomachs of $282 \mathrm{~A}$. americanus collected in the Mid-Atlantic Bight during July 2002 in the NMFS sea scallop survey that was a part of this study. Combining the frequency of sea scallops in their stomachs with the high abundances of $A$. americanus (often 10000 to 20000 tow $^{-1}$ or higher compared to a tow path of about $4500 \mathrm{~m}^{2}$ ) indicates that direct predation of scallop spat by $A$. americanus is capable of impacting sea scallop recruitment.

Sea scallop pediveligers are capable of delaying settlement for at least a few days if bottom conditions are unsatisfactory for settlement (Culliney 1974), and post-settlement juveniles may swim short distances to escape sea star predation. Thus, it is possible that some of the effects observed here were due to predator avoidance rather than direct predation. However, the nearly ubiquitous distribution of Astropecten americanus in deep water would make it difficult for juvenile scallops to avoid this sea star at these depths. The fact that sea scallops are often seen in the stomachs of $A$. americanus and the numerous observations of consumption of scallops by Asterias spp., imply that avoidance behavior can at most be only a partial explanation for the observed patterns.

Sea scallop recruits in the 40 to $69 \mathrm{~mm}$ range are about 2 yr old, and thus would have been only subject to Astropecten americanus predation for 18 to 22 mo previously. The hypothesis that the negative relationship observed between $A$. americanus and sea scallop recruits was due to predation requires an assumption that aggregations of $A$. americanus are persistent, so that high abundances of these sea stars observed in a given year correspond to high densities $2 \mathrm{yr}$ previously. In deep water $(>75 \mathrm{~m}), A$. americanus appear always to be at high density, so the persistence criterion would be met in these locations. To test persistence in shallower water, 2 stations on the 2000 survey where $A$. americanus were unusually abundant (depths of 68 and $65 \mathrm{~m}$ ) were resampled in 2001 and 2002. A. americanus catches in 2000 to 2002 at the first site were 20600,20160 , and 17504 , respectively, and were 17316 in 2000 and 16120 in 2002 at the second site (a photograph of the catch at this site in 2001 showed that it was dominated by $A$. americanus, but due to an oversight, no sea star subsample was taken), indicating that aggregations of these sea stars can per- 
sist for several years. Boesch (1979) sampled a number of fixed stations in the Mid-Atlantic several times a year during 1975 to 1977 , and similarly found little temporal variation in catches of $A$. americanus and Asterias spp.

Some species of Astropecten may seasonally migrate (Pabst \& Vicentini 1978, Nojima 1983, Lemmens et al. 1995, Freeman et al. 2001). The populations in each of these cases were near-shore, where the environment can change substantially, with horizontal movements on the order of hundreds of meters. A. araniacus, whose maximum size is much larger than that of $A$. americanus, typically move about $10 \mathrm{~m} \mathrm{~d}^{-1}$ (Burla et al. 1972), suggesting that it would be able to migrate $<2 \mathrm{~km}$ in $6 \mathrm{mo}$. Bottom temperatures or other environmental variables are unlikely to change much on the scale of a few kilometers offshore, making seasonal migrations of $A$. americanus unlikely. As indicated above, aggregations of $A$. americanus appear to persist at a location for several years.

The time-lag between Astropecten americanus predation and observed scallop recruitment is likely to be at least one of the reasons why $A$. americanus mean weight was a statistically significant predictor of sea scallop recruitment. Though asteroid growth is highly variable, there still should be a correlation between size and age. A. americanus $<2$ yr old would not have had the opportunity to consume the observed scallop recruits because they would have settled after the scallops. This may explain the outlier station in Fig. 4 b, where over $50000 \mathrm{~A}$. americanus along with moderate scallop recruitment were observed; the mean weight of the A. americanus at this station was among the lowest of all stations ( $<1 \mathrm{~g}$, Fig. 8).

Astropecten americanus were confined to deeper water at higher latitudes, consistent with the idea that they are limited by winter minimum temperatures (Franz et al. 1981). The pattern of abundance of Asterias spp., which declines strongly with increasing depth in the Mid-Atlantic Bight, cannot be as simply explained by temperature limitation. Indeed, bottom temperatures at 70 to $110 \mathrm{~m}$ depth in the Mid-Atlantic are well within the tolerance of $A$. forbesi and, with the possible exception of the most southern areas, A. vulgaris as well (Smith 1940, MacKenzie 1969, Sloan 1980, Franz et al. 1981, Barbeau \& Scheibling 1994). A. vulgaris was commonly observed at these depths in the samples taken on Georges Bank and neighboring areas, and can occur to depths of $400 \mathrm{~m}$ or more (Vevers 1949). Because neither temperature limitation nor direct depth effects can explain the reduced number of Asterias spp. in deep water in the Mid-Atlantic, it appears that the high density of Astropecten americanus in deeper water is at least in part responsible for the low Asterias spp. abundance. Confirming this idea is the fact that Asterias spp. were absent from the majority of the Georges Bank stations with high Astropecten americanus abundance even although they were common in most other deep-water stations in this area.

A negative interaction between Astropecten americanus and Asterias spp. may appear surprising, since adults of these 2 groups do not directly compete, with Asterias spp. mainly preying on items too large for $A$. americanus to consume. The fact that $A$. americanus abundance is a significant positive predictor of Asterias spp. weight suggests that $A$. americanus are reducing the number of juvenile Asterias spp. A. americanus may be outcompeting young Asterias spp. for food when these juveniles' diet is similar to that of adult $A$. americanus. It is possible that $A$. americanus is consuming newly settled Asterias spp., although no Asterias spp. have been found in the stomachs of $A$. americanus (Franz \& Worley 1982, Smereka 2003). A. americanus may also be reducing the number of Asterias spp. due to what may be termed 'preemptive competition', whereby A. americanus consume most of the potential prey items of Asterias spp. before they can grow to a size normally taken by this genus. While preemptive competition is an unusual concept, it may be an important process in many systems of organisms with complex life-histories and large ontogenetic changes in size and diet, as is common in marine ecosystems. A. americanus may be an unusual type of dominant predator that structures the benthic invertebrate community by removing large quantities of juvenile invertebrates as well as effectively competing against other predators.

The mean weight of Astropecten americanus appears to be unrelated to its abundance at densities of less than about 5000 tow $^{-1}$, but drops sharply at higher densities. As discussed above, migration is an unlikely explanation for this phenomenon. Asteroid growth is highly variable, depending on food supply, and they can survive long periods with little or no food by growing slowly or even reducing their size (Vevers 1949, Hancock 1958, Christensen 1970). At A. americanus densities of $<5000$ tow $^{-1}$, it appears that their growth rate (and probably their consumption rate) does not depend on their density, suggesting that they are feeding near their maximum rate. At $A$. americanus densities $>5000$ tow $^{-1}$, mean size declines rapidly with abundance, probably because of decreased growth (and possibly also increased mortality) due to food limitation. A similar pattern was noted for Asterias vulgaris populations in Canada (Smith 1940). The data from the present study suggest that density-dependent processes may also be occurring for Asterias spp. and Cancer spp., although the effects appear much weaker, probably because of lower densities. 
In an observational study such as that presented here, there is always some uncertainty as to the mechanisms that produced the observed relationships. While direct predation is the most likely explanation for the negative associations between sea scallop recruits and sea stars, it is possible that predator avoidance by settling pediveligers or by post-settlement juveniles was also a contributing factor. While there is some uncertainty as to the mechanism by which Astropecten americanus is excluding Asterias spp., it is clear that high levels of $A$. americanus do reduce Asterias spp. abundance. This study has demonstrated how the patterns of recruitment of an important commercial species can be fitted into an ecosystem context.

Acknowledgements. This article benefitted from comments from and discussions with A. Chute, L. Kaufman, P. Rago, M. Terceiro and the reviewers, and from technical assistance from A. Chute. I also thank the crew of the RV 'Albatross IV' and members of the NEFSC Ecosystems Survey Branch for assistance with the sampling.

\section{LITERATURE CITED}

Barbeau MA, Scheibling RE (1994) Temperature effects on predation of juvenile sea scallops [Placopecten magellanicus (Gmelin)] by sea stars (Asterias vulgaris Verrill) and crabs (Cancer spp. irroratus Say). J Exp Mar Biol Ecol 182:27-47

Barbeau MA, Hatcher BG, Scheibling RE, Hennigar AW, Taylor LH, Risk AC (1996) Dynamics of juvenile sea scallop (Placopecten magellanicus) and their predators in bottom seeding trials in Lunenburg Bay, Nova Scotia. Can J Fish Aquat Sci 53:2494-2512

Barbeau MA, Scheibling RE, Hatcher RG (1998) Behavioral responses of predatory crabs and sea stars to varying density of juvenile sea scallops. Aquaculture 169:87-98

Bishop MJ, Rivera JA, Irlandi EA, Ambrose WG Jr, Peterson $\mathrm{CH}$ (2005) Spatio-temporal patterns in the mortality of bay scallop recruits in North Carolina: investigation of a life history anomaly. J Exp Mar Biol Ecol 315:127-146

Boesch DF (1979) Benthic ecological studies: macrobenthos, Chapter 6. In: Special report in applied marine science and ocean engineering; no. 194. Virginia Institute of Marine Science, Gloucester Point, VA

Burla H, Ferlin V, Pabst B, Ribi G (1972) Notes on the ecology of Astropecten araniacus. Mar Biol 14:235-241

Chambers JM, Cleveland WS, Kleiner B, Tukey PA (1983) Graphical methods for data analysis. Duxbury, Boston, MA

Christensen AM (1970) Feeding biology of the sea-star Astropecten irregularis. Ophelia 8:1-134

Cliche G, Giguère M, Vigneau S (1994) Dispersal and mortality of sea scallops, Placopecten magellanicus (Gmelin 1791), seeded on the sea bottom off îles-de-la-Madeleine. J Shellfish Res 13:565-570

Collette BB, Klein-MacPhee G (2002) Bigelow and Schroeder's fishes of the Gulf of Maine, 3rd edn. Smithsonian Institution Press, Washington, DC

Culliney JL (1974) Larval development of the giant scallop, Placopecten magellanicus (Gmelin). Biol Bull (Woods Hole) 147:321-332
Elner RW, Jamieson GS (1979) Predation of sea scallops, Placopecten magellanicus, by the rock crab, Cancer spp. irroratus, and the American lobster, Homarus americanus. J Fish Res Board Can 36:537-543

Franz DR, Worley EK (1982) Seasonal variability of prey in the stomachs of Astropecten americanus (Echinodermata: Asteroidea) from off Southern New England, USA. Estuar Coast Shelf Sci 14:355-368

Franz DR, Worley EK, Merrill AS (1981) Distribution patterns of common seastars of the Middle Atlantic Continental Shelf of the Northwest Atlantic (Gulf of Maine to Cape Hatteras). Biol Bull (Woods Hole) 160:394-418

Fraschetti S, Giangrande A, Terlizzi A, Boero F (2003) Preand post-settlement events in benthic community dynamics. Oceanol Acta 25:285-295

Freeman SM, Richardson RA, Seed R (2001) Seasonal abundance, spatial distribution, spawning and growth of Astropecten irregularis (Echinodermata:Asteroidea). Estuar Coast Shelf Sci 53:39-49

Gedamke T, DuPaul WD, Hoenig JM (2004) A spatially explicit open-ocean DeLury analysis to estimate gear efficiency in the dredge fishery for sea scallop Placopecten magellanicus. N Am J Fish Manag 24:335-351

Gosselin LA, Qian PY (1997) Juvenile mortality in benthic marine invertebrates. Mar Ecol Prog Ser 146:265-282

Guay M, Himmelman JH (2004) Would adding scallop shells (Chlamys islandica) to the sea bottom enhance recruitment of commercial species? J Exp Mar Biol Ecol 312: 299-317

Hancock DA (1958) Notes on starfish on an Essex oyster bed. J Mar Biol Assoc UK 37:565-589

Hart DR, Chute AS (2004) Essential fish habitat source document: sea scallop, Placopecten magellanicus, life history and habitat characteristics, 2nd edn. NOAA Tech Memo NMFS NE-189

Hunt HL, Scheibling RE (1997) Role of early post-settlement mortality in recruitment of benthic marine invertebrates. Mar Ecol Prog Ser 155:269-301

Lemmens JWTJ, Arnold PW, Birtles RA (1995) Distribution patterns and selective feeding in two Astropecten species (Asteroidea: Echinodermata) from Cleveland Bay, Northern Queensland. Mar Freshw Res 46:447-455

Link JS, Almeida FP (2000) An overview and history of the food web dynamics program of the Northeast Fisheries Science Center, Woods Hole, Massachusetts. NOAA Tech Memo NMFS-NE-159

MacKenzie CL Jr (1969) Feeding rates of starfish, Asterias forbesi (Desor), at controlled water temperatures and during different seasons of the year. Fish Bull (Wash DC) 68: $67-72$

MacKenzie CL Jr, Radosh DJ, Reid RN (1985) Densities, growth, and mortality of juveniles of the surf clam (Spisula solidissima) (Dillwyn) in the New York Bight. J Shellfish Res 5:81-84

McGarvey R, Serchuk FM, McLaren IA (1992) Statistics of reproduction and early life history survival of the Georges Bank sea scallop (Placopecten magellanicus) population. J Northwest Atl Fish Sci 13:83-99

Merrill AS, Edwards RL (1976) Observations on mollusks from a navigation buoy with special emphasis on the sea scallop, Placopecten magellanicus. Nautilus 90:54-61

NEFSC (Northeast Fisheries Science Center) (2004) 39th Northeast Regional Stock Assessment Workshop (39th SAW) assessment report. Ref Doc 04-10b, Northeast Fisheries Science Center, Woods Hole, MA

Nojima S (1983) Ecological studies on the sea star Astropecten latespinosus (Meissner) V. Pattern of spatial distribution 
and seasonal migration with special reference to spawning aggregation. Publ Amakusa Mar Biol Lab 7:1-16

Ólafsson EB, Peterson CH, Ambrose WG Jr (1994) Does recruitment limitation structure populations and communities of macro-invertebrates in marine soft-sediments: the relative significance of pre- and post-settlement processes. Oceanogr Mar Biol Annu Rev 32:65-109

Pabst B, Vicentini H (1978) Dislocation experiments in the migrating sea star Astropecten jonstoni. Mar Biol 48: 271-278

Peterson CH, Summerson HC (1992) Basin-scale coherence of population dynamics of an exploited marine invertebrate, the bay scallop: implications of recruitment limitation. Mar Ecol Prog Ser 90:257-272

Ross DJ, Johnson CR, Hewitt CL (2002) Impact of introduced seastars Asterias amurensis on survivorship of juvenile commercial bivalves Fulvia tenuicostata. Mar Ecol Prog Ser 241:99-112

Schick DF, Shumway SE, Hunter MA (1988) A comparison of growth rates between shallow water and deep water populations of scallops, Placopecten magellanicus (Gmelin, 1791), in the Gulf of Maine. Am Malacol Bull 6:1-8

Schwartz FJ, Porter HJ (1977) Fishes, macroinvertebrates, and their ecological interrelationships with a calico scallop bed off North Carolina. Fish Bull (Wash DC) 75:427-446 Serchuk FM, Wigley SE (1986) Evaluation of USA and Cana-

Editorial responsibility: Howard I. Browman (Associate Editor-in-Chief), Storebø, Norway dian research vessel surveys for sea scallops, (Placopecten magellanicus), on Georges Bank. J Northwest Atl Fish Sci $7: 1-13$

Serchuk FM, Wood PW Jr, Posgay JA, Brown BE (1979) Assessment and status of sea scallop, (Placopecten magellanicus), populations off the northeast coast of the United States. Proc Natl Shellfish Assoc 69:161-191

Sloan NA (1980) Aspects of the feeding biology of asteroids. Oceanogr Mar Biol Annu Rev 18:57-124

Smereka P (2003) Dietary preference and foraging patterns in the sea star Astropecten americanus (Echinodermata: Asteroidea). Distinction thesis, Boston University, Boston, MA

Smith GFM (1940) Factors limiting distribution and size in the starfish. J Fish Res Board Can 5:84-103

Thouzeau G, Robert G, Smith SJ (1991) Spatial variability in distribution and growth of juvenile and adult sea scallops Placopecten magellanicus (Gmelin) on eastern Georges Bank (Northwest Atlantic). Mar Ecol Prog Ser 74:205-218

Vevers HG (1949) The biology of Asterias rubens L.: growth and reproduction. J Mar Biol Assoc UK 28:165-187

Wigley RL, Theroux RB (1981) Atlantic continental shelf and slope of the United States - macrobenthic invertebrate fauna of the Middle Atlantic Bight region - faunal composition and quantitative distribution. Prof Pap US Geol Surv 529-N

Submitted: October 20, 2004; Accepted: July 17, 2005

Proofs received from author(s): December 6, 2005 